\title{
Railway transportation of dangerous goods: a bibliometric aspect
}

\author{
Tetiana Kolesnykova ${ }^{1, *}$, Olena Matveyeva ${ }^{1}$, Lev Manashkin ${ }^{2}$, and Maxym Mìshchenko ${ }^{3}$ \\ ${ }^{1}$ Dnipro National University of Railway Transport named after Academician V. Lazaryan, Scientific and Technical Library, Dnipro, \\ Ukraine \\ ${ }^{2}$ Self-Employed, West Hartford, Connecticut, USA \\ ${ }^{3}$ Dnipro National University of Railway Transport named after Academician V. Lazaryan, Department of Economics and \\ Management, Dnipro, Ukraine
}

\begin{abstract}
The purpose of this paper is to research and define the promising worldwide scientific trends in the field of railway transportation of various dangerous goods. To obtain relevant empirical data, the authors reviewed the world literature on paper topic using Scopus and Web of Science citation bases. We determined that this research was focused on several major thematic areas: 1) automation and telematics systems; 2) navigation systems; 3) logistics; 4) energy; 5) locomotives; 6) freight cars; 7) materials; 8) rails; 9) impact on the environment and people. The article used mapping, ensuring a visual perspective for researchers and helping to understand general situations in specific subject areas of the research. This study provides useful information concerning the development of the field of research for the railway transportation of dangerous goods, identifying those academics (authors, countries and institutions) that have made the greatest contribution to its development and defining the priority research directions
\end{abstract}

\section{Introduction}

The topic of dangerous goods refers primarily to the transport of the respective goods including the interim storage, if caused by the transport.

Transportation of dangerous goods (TDG) include the activities related to the movement of dangerous goods from their place of manufacture or storage to their destination with the preparation of cargo, packaging, vehicles and crew, reception of goods, carrying out cargo operations and short-term storage of goods at all stages of their transfer [1].

Dangerous goods (DG) are items or substances that when transported are a risk to health, safety, property or the environment [2]. There are the following types of hazard connected with dangerous goods: flammability, explosion hazard, harmfulness, toxicity, infectious hazard, corrosion, oxidative properties of goods, radioactivity [1, p. 21].

The rapidly growing needs of society bring with them, on the one hand, the development of industry, new techniques and technologies, and on the other, the use of new types of hazardous substances. Currently, a large number of hazardous substances are transported by rail, which increases the risk of incidents during transportation. Thus, the statistics of rail transportation in the USA (2015 - Aug. 2018) shows an increase in the volume of traffic, including of DG: oil and oil products by 12,780 carloads, or by $28.8 \%$; chemistry - by 11,911 carloads,

or

by

$7.8 \%$ (https://www.advis.ru/php/view_news.php?id=9009E291 -1A24-A640-A324-64F6255B9A-92).

The measures to minimize risks in TDG to acceptable levels are discussed by $M$. Šolc and $M$. Hovanec [3]. The most important measure here is the rules for the transport of dangerous goods, the responsible implementation of which by each of the countries will significantly improve safety. For example, 46 countries in Europe, Asia and Africa (as of May 1, 2019), united by international traffic, agreed and signed the Convention concerning International Carriage by Rail (COTIF). Appendix C - Regulations concerning the International Carriage of Dangerous Goods by Rail (RID) [4]. The regulations relate to procedural and transportation requirements and exemptions to ensure the safety during carriage and entered into force on January 1, 2019. Changes in RID 2019 include the classification, packing and labelling of items containing dangerous substances, a revision of the classification codes for corrosive substances, new packing instructions for damaged or defective lithium batteries and destructive testing of gas cylinders.

Given the recognized urgent need in different countries to develop the topic of DG transportation by rail, it becomes important to clearly understand the current state of research activity in this area.

At the same time, thorough bibliometric studies do not exist so far that illustrate the overall research activity in the field of TDG over a long time span.

\footnotetext{
Corresponding author: kolesnykova@,diit.edu.ua, chief.library@gmail.com
} 
This article aims to study the flow of publications of the global research environment in the field of transportation of dangerous goods by a particular mode of transport - rail, using bibliometric analysis.

The purpose of this paper is to research and define the promising worldwide scientific trends in the field of railway transportation of various dangerous goods.

\section{Literature review}

Railway transport plays a key role in the transportation of dangerous goods (DG). It is for this reason that improving the safety of rail transport is a priority for both industry and governments.

The consolidation of a body of knowledge (BOK) in the domain of formal methods for railway systems safety would not be possible if there had not been done much research work already in this field since many years.

Measuring the size of the global flow of publications on various aspects of cargo transportation and its quality characteristics are very important, including for allocation of funding and prioritization of resources.

So, scientists of United Kingdom, studying the current state of research in the field of Decision support systems (DSS) decision support systems for logistics, established the following. The bibliometric analysis showed that DSS for sustainable logistics is an emerging field; however, it is still evolving but at a slower pace [5]. The inherent key themes were decision models and frameworks to address sustainable logistics issues covering transport, distribution and third-party logistics. The most prominent sustainable logistics issue was carbon footprinting.

In the article [6], in relation to the necessary identification of established knowledge in the field of railways, the authors applied lattice-theoretical methods for analysing formal concepts in order to structure and systematize large volumes of relevant bibliometric data from the rail literature flow.

The influence of random factors and events that can lead to an accident and threaten not only the safety of rail transport, but also the life and health of people, as well as pose a threat to the environment, are always relevant for researchers $[7,8]$.

The results of bibliometric analysis in the field of road transport medicine have shown that researches are increasing annually, and the cooperation of scientists from different countries is growing [9]. But still, these rates are relatively low compared to other research areas.

Studies of rail transport show that they have a high level of penetration of connections in various interdisciplinary areas, especially technical ones [10]. The efforts of the inventors, enshrined in their technical solutions, are aimed at ensuring improved safety, reducing the negative impact on the environment, the use of renewable energy sources, energy efficiency.

Chinese scientists, using bibliometric analysis, systemic induction and deduction, explore the topic of urban rail transport safety in several developed countries (the USA, UK, Japan and South Korea) in its current state and trends, including the future vision of traffic development and preventative security measures [11].

\section{Method}

This research is characterized as theoretical in nature. The study was conducted using bibliometric analysis methods, with recognized scientometric analysis tools combined with visualization. To obtain relevant empirical data, the authors reviewed the world literature on paper topic using Scopus (Elsevier) and Web of Science (Clarivate Analytics) citation bases.

Bibliometric analysis is a method of displaying the main authors, journals and keywords by a specific topic. J.L.S. Santos, M. Uriona-Maldonado, and R.N.M.D. Santos [12] state that these methods are tools based on a scientifically recognized methodological theoretical basis that allows the use of statistical and mathematical methods to compare information from bibliographic records of documents stored in databases.

Our paper used mapping that provides a visual perspective for researchers and helps to understand general situations in specific subject areas of the study.

To manage and tabulate the collected data we used two software programs: (i) Bibexel and (ii) VosViewer.

In the work we used the Bibexel program (https://bibliometrie.univie.ac.at/bibexcel/), created by Olle Persson, a professor of library science and computer science at the Swedish Umeå University [13]. It allows analyzing the metadata, namely, the links between the co-authors and the analyzed abstracts (to identify the most "top" keywords in them) [14].

VosViewer, developed by N.J. van Eck, and L. Waltman [15] is a software for visualizing knowledge blocks of documents, especially suitable for analyzing large-scale data sets and building complex networks. In particular, it can be used to build bibliometric networks based on data downloaded from bibliographic databases, such as the Web of Science (CC) and Scopus. We used the VosViewer version 1.6.11.

In order to identify and evaluate changes relating to scientific activity and consider a more recent situation specifically, we analyzed two time intervals $(t)$. The first time interval is from 1975 to June 2019 (t1), the second is from 2015 to June 2019 (t2).

Search strategies. Using the Scopus and WoS topic search, the following query was applied: dangerous goods, railway ('dangerous goods' AND railway).

To clarify the data, we used the subject areas: 1) automation and telematics systems; 2) navigation systems; 3) logistics; 4) energy; 5) locomotives; 6) freight cars; 7) materials; 8) rails; 9) impact on the environment and people.

Categorization of data. The categorization technique was as follows. Bibliometric data of all types of publications were extracted from each database for two time intervals $-\mathrm{t} 1$ and $\mathrm{t} 2$. The data were then classified according to different parameters (for example, year of publication, authors of publication, place of work of authors, country, type of document 
published, source, language of publication, areas of knowledge, funders).

For the collection and processing of references, we used EndNote software - a bibliographic manager that works in integration with the Web of Science.

Scientometric analysis. Transportation of dangerous goods is an interdisciplinary research area, which includes the integration of several sciences: engineering, chemical, medical, environmental sciences, etc. Unfortunately, world science is not sufficiently represented by research on this topic using bibliometrics, which is a statistical method for studying scientific publications, citations, patent documents and reports. But although bibliometric analysis is a process of quantitative analysis, its results are still qualitative [16].

One of the research methods of this article is based on scientometrics and involves combining software output information with manual interpretation to obtain final results or conclusions. As mentioned earlier, we used scientometric analysis software (VosViewer, BibExcel), which assists researchers in scientific statistics and network mapping of literature.

\section{Findings}

The analysis of two time intervals for identifying and evaluating changes related to scientific activity showed the following results. During the first time interval from 1975 to June 2019 (t1), there were identified 193 Scopus publications (p1) and $87 \mathrm{WoS}$ (CC) publications (p2). In the subsequent period from 2015 to June 2019 (t2), the same search strategy identified: 38 Scopus publications (p1) and 40 WoS (CC) publications (p2) (Figure 1).

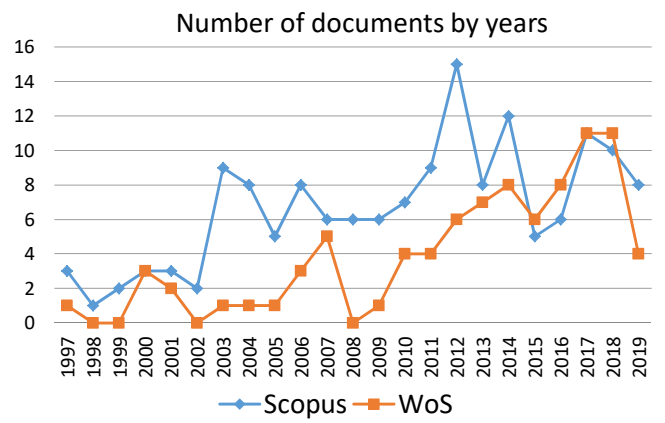

Fig. 1. Number of documents by years (Scopus, WoS)

When refining data using 9 subject areas, it was found that the same article may relate to different subject areas.

The trend shown in Table 1 and Table 2 demonstrates how research on the transport of dangerous goods attracts the attention of many scientists around the world.

The top subject areas (by the number of articles in each of the databases) for the entire observation period (t1) became the areas "Materials", "Rails", "Logistics", "Impact on the environment" (Table 1).

But although the data on top research areas for the last 5 years $(\mathrm{t} 2)$ for Scopus and WoS differ significantly in percentage, they still show an increase in new areas: "Automation and telematics systems", "Navigation systems", "Logistics", "Energy". There is stated a decrease in interest in the "Locomotives" subject area (Table 2).

Table 1. Number of documents by thematic areas

\begin{tabular}{|l|c|c|c|c|}
\hline \multirow{4}{*}{ Thematic areas } & \multicolumn{4}{|c|}{ Number of documents } \\
\cline { 2 - 5 } & \multicolumn{2}{|c|}{ Scopus } & \multicolumn{2}{c|}{ Web of Science } \\
\cline { 2 - 5 } & $\begin{array}{c}\text { For all } \\
\text { the time } \\
\text { (t1) }\end{array}$ & $\begin{array}{c}\text { In 5 } \\
\text { years } \\
\text { (t2) }\end{array}$ & $\begin{array}{c}\text { For all } \\
\text { the time } \\
\text { (t1) }\end{array}$ & $\begin{array}{c}\text { In 5 } \\
\text { years } \\
\text { (t2) }\end{array}$ \\
\hline $\begin{array}{l}\text { Automation and } \\
\text { telematics systems }\end{array}$ & 6 & 3 & 1 & 1 \\
\hline Navigation systems & 6 & 3 & 4 & 3 \\
\hline Logistics & 34 & 14 & 5 & 4 \\
\hline Energy & 15 & 8 & 3 & 2 \\
\hline Locomotives & 7 & 2 & 2 & 0 \\
\hline Freight cars & 17 & 6 & 3 & 3 \\
\hline Materials & 114 & 23 & 27 & 13 \\
\hline Rails & 101 & 27 & 37 & 17 \\
\hline $\begin{array}{l}\text { Impact on the envi- } \\
\text { ronment and people }\end{array}$ & 33 & 10 & 6 & 3 \\
\hline
\end{tabular}

Table 2. The percentage of new articles

\begin{tabular}{|l|c|c|}
\hline \multicolumn{1}{|c|}{ Thematic areas } & Scopus & WoS \\
\hline Automation and telematics systems & $50.00 \%$ & $100.00 \%$ \\
\hline Navigation systems & $50.00 \%$ & $75.00 \%$ \\
\hline Logistics & $41.18 \%$ & $80.00 \%$ \\
\hline Energy & $53.33 \%$ & $66.67 \%$ \\
\hline Locomotives & $28.57 \%$ & $0.00 \%$ \\
\hline Freight cars & $35.29 \%$ & $100.00 \%$ \\
\hline Materials & $20.18 \%$ & $48.15 \%$ \\
\hline Rails & $26.73 \%$ & $45.95 \%$ \\
\hline Impact on the environment and people & $30.30 \%$ & $50.00 \%$ \\
\hline
\end{tabular}

Main journals. The documents obtained from Scopus $(\mathrm{p} 1=193)$ and WoS $(\mathrm{p} 2=87)$ were published in various sources (Table 3 and Table 4).

Table 3 shows that "Safety Science" (SNIP 2.251, CiteScore 4.49), "Accident Analysis and Prevention" (SNIP 2.047, CiteScore 3.82), "Tiedao Xuebao Journal of the China Railway Society" (SNIP 0.894, CiteScore 0.77 ) have been the journals of interest to authors for a long time (t1 and t2). The journals "Safety Science" and "Accident Analysis and Prevention" are also indexed in WoS. The journal "Safety Science" is in the first quartile by WoS categories "Engineering, industrial" and "Operations research \& management science". The "Accident Analysis and Prevention" journal is in the first quartile by the categories "Ergonomics", "Public, environmental \& occupational health (SSCI)" and "Social sciences, interdisciplinary", and in the second quartile by the category "Transportation".

The "Journal of Hazardous Materials" published 2 of the most highly cited to date articles on the topic of TDG. The first article by P. H. Bottelberghs "Risk analysis and safety policy developments in the Netherlands" (123 citations in Scopus) [17] is affiliated with the Ministry of Housing, Netherlands. The second article by B. Fabiano, F. Currò, E. Palazzi, R. Pastorino 
"A framework for risk assessment and decision-making strategies in dangerous good transportation" (110 citations in Scopus) [18] is affiliated with the University of Genoa, Italy.

Table 3. Number of documents by sources (Scopus) (At least two documents)

\begin{tabular}{|l|c|l|c|}
\hline \multicolumn{2}{|c|}{ For all the time } & \multicolumn{2}{c|}{ In 5 years } \\
\hline Source name & $\begin{array}{l}\text { Number of } \\
\text { documents }\end{array}$ & Source name & $\begin{array}{l}\text { Number of } \\
\text { documents }\end{array}$ \\
\hline $\begin{array}{l}\text { Journal of } \\
\text { Hazardous } \\
\text { Materials }\end{array}$ & 20 & $\begin{array}{l}\text { Accident } \\
\text { Analysis and } \\
\text { Prevention }\end{array}$ & 3 \\
\hline $\begin{array}{l}\text { Gigiena I } \\
\text { Sanitariia }\end{array}$ & 11 & Safety Science & 3 \\
\hline Safety Science & 7 & $\begin{array}{l}\text { MATEC Web } \\
\text { of Conferences }\end{array}$ & 2 \\
\hline $\begin{array}{l}\text { Tiedao Xuebao } \\
\text { Journal of the } \\
\text { China Railway } \\
\text { Society }\end{array}$ & 7 & $\begin{array}{l}\text { Tiedao Xuebao } \\
\text { Journal of the } \\
\text { China Railway } \\
\text { Society }\end{array}$ & 2 \\
\hline $\begin{array}{l}\text { Accident } \\
\text { Analysis and } \\
\text { Prevention }\end{array}$ & 6 & $\begin{array}{l}\text { Procedia } \\
\text { Computer } \\
\text { Science }\end{array}$ & 2 \\
\hline $\begin{array}{l}\text { Clinics in Occu- } \\
\text { pational and } \\
\text { Environmental } \\
\text { Medicine }\end{array}$ & 5 & $\begin{array}{l}\text { Transportation } \\
\text { Research } \\
\text { Procedia }\end{array}$ & 2 \\
\hline
\end{tabular}

Table 4. Number of documents by source (WoS) (At least two documents)

\begin{tabular}{|l|c|c|}
\hline \multicolumn{1}{|c|}{ Source name } & $\begin{array}{c}\text { Number of } \\
\text { documents (for } \\
\text { all the time) }\end{array}$ & $\begin{array}{c}\text { Two } \\
\text { documents } \\
\text { in 5 years }\end{array}$ \\
\hline $\begin{array}{l}\text { Accident Analysis and } \\
\text { Prevention }\end{array}$ & 2 & \\
\hline $\begin{array}{l}\text { Advanced Materials } \\
\text { Research }\end{array}$ & 2 & \\
\hline $\begin{array}{l}\text { Canadian Journal of Civil } \\
\text { Engineering }\end{array}$ & 2 & 2 \\
\hline $\begin{array}{l}\text { Case Studies on Transport } \\
\text { Policy }\end{array}$ & 2 & \\
\hline $\begin{array}{l}\text { Chemical Engineering } \\
\text { Transactions }\end{array}$ & 2 & \\
\hline $\begin{array}{l}\text { Communications in Compu- } \\
\text { ter and Information Science }\end{array}$ & 2 & \\
\hline $\begin{array}{l}\text { Computers Operations } \\
\text { Research }\end{array}$ & 2 & 2 \\
\hline $\begin{array}{l}\text { Interdisciplinary Descrip- } \\
\text { tion of Complex systems }\end{array}$ & 2 & \\
\hline $\begin{array}{l}\text { Journal of Loss Prevention } \\
\text { in the Process industries }\end{array}$ & 2 & \\
\hline $\begin{array}{l}\text { Journal of Rail Transport } \\
\text { Planning Management }\end{array}$ & 2 & \\
\hline Proceedings of Spie & 2 & \\
\hline Safety Science & 2 & \\
\hline Transport & 2 & \\
\hline $\begin{array}{l}\text { Transport Means } \\
\text { Proceedings of the } \\
\text { International Conference }\end{array}$ & 2 & \\
\hline & 2 & \\
\hline
\end{tabular}

\begin{tabular}{|l|c|l|}
\hline $\begin{array}{l}\text { Transportation Research } \\
\text { Part C Emerging } \\
\text { Technologies }\end{array}$ & 2 & \\
\hline $\begin{array}{l}\text { Transportation Research } \\
\text { Part E Logistics and } \\
\text { Transportation Review }\end{array}$ & 2 & \\
\hline
\end{tabular}

As indicated in Table 4, only for the last 5 years (t2) publications on the transportation of dangerous goods by rail have been presented in the journals "Case Studies on Transport Policy" "Interdisciplinary Description of Complex systems", "Journal of Rail Transport Planning Management", "Safety Science". The results show that journals do not have an increase in publications in the field of TDG in recent years.

The journals "Case Studies on Transport Policy" (SNIP 1.06, CiteScore 1.58), "Journal of Rail Transport Planning Management" (SNIP 1.123, CiteScore 1.78), "Safety Science" (see above) are also indexed in Scopus.

The most productive authors. As for the most productive authors, we identified 12 scientists who have 4 or more publications in Scopus for $\mathrm{t} 1$ (Figure 2).

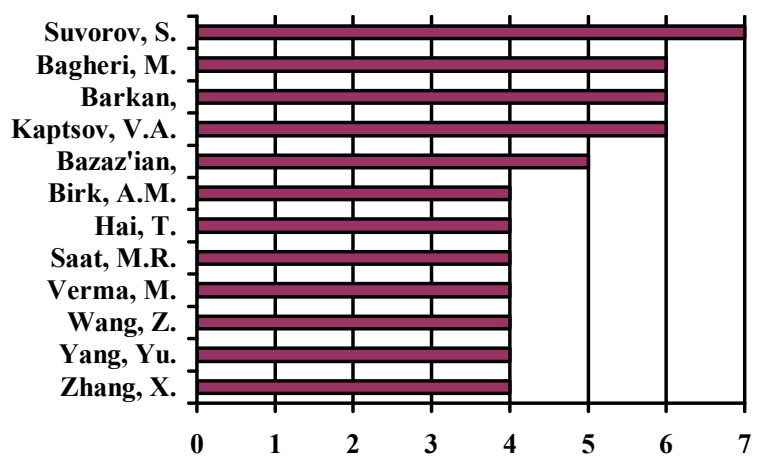

Fig. 2. Authors, who published at least 4 papers (1975-2019, Scopus)

These are the following researchers:

- Suvorov, S. V. - Inst Zheleznodorozhnoj Gigieny MPS, Moscow, Russian Federation, h-index 2, total documents in Scopus - 71 .

- Bagheri, M. - Iran University of Science and Technology, Tehran, Iran, h-index 6, total documents in Scopus -28 .

- Barkan, Christopher P.L. - University of Illinois at Urbana-Champaign, Urbana, United States, h-index 22, total documents in Scopus - 104.

- Kaptsov, V. A. - Joint Stock Company "Russian Railways", Moscow, Russian Federation, h-index 2, total documents in Scopus - 121 .

- Bazaz'ian, A. G. - non-affiliated, h-index 1, total documents in Scopus -8 .

- Birk, A. M. - Queen's University, Kingston, Kingston, Canada, h-index 18, total documents in Scopus - 167.

- Hai, Tao - Beijing Jiaotong University, Beijing, China, h-index 2, total documents in Scopus - 5 .

- Saat, M. R. - Association of American Railroads, Washington, D.C., United States, h-index 11, total documents in Scopus - 28 . 
- Verma, M. - McMaster University, DeGroote School of Business, Hamilton, Canada, h-index 12, total documents in Scopus - 36 .

- Wang, Zhe - Southwest Jiaotong University, Chengdu, China, h-index 1, total documents in Scopus - 4 .

- Yang, Yuefang - Beijing Jiaotong University, Beijing, China, h-index 2, total documents in Scopus - 11 .

- Zhang, Xingchen - Beijing Jiaotong University, Beijing, China, h-index 5, total documents in Scopus - 68 .

Iranian author M. Bagheri has a joint publication with authors from Canada F. Saccomanno, S. Chenouri, $\mathrm{L}$. $\mathrm{Fu}$ "Reducing the threat of in-transit derailments involving dangerous goods through effective placement along the train consist" (33 citations in Scopus) [19].

The number of authors having 4 or more publications in WoS is rather insignificant, therefore we identified authors who have 3 or more papers (Figure 3 ).

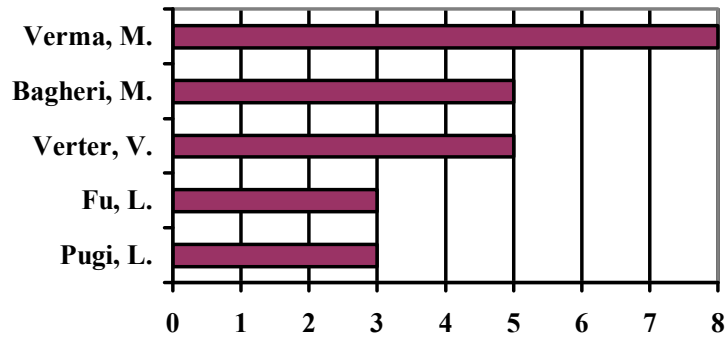

Fig. 3. Authors, who published at least 3 papers (1997-2019, WoS)

These are the following researchers:

- Verma, M. - McMaster University, Hamilton, Canada, h-index 14, total documents in $\mathrm{WoS}-36$.

- Bagheri, M. - Iran University of Science and Technology, Tehran, Iran, h-index 7, total documents in WoS -24 .

- Verter, V. - McGill Univ, Montreal, Canada, h-index 29, total documents in WoS - 79.

- Fu, Liping - Jiangsu Normal Univ, Xuzhou, Peoples R China, h-index 23, total documents in WoS -181 .

- Pugi, L. - Univ Florence, Florence, Italy, h-index 16, total documents in WoS - 126.

The authors M. Verma and V. Verter from Canada and $\mathrm{M}$. Bagheri from Iran have a joint publication "Transport Mode Selection for Toxic Gases: Rail or Road?" (23 citations in WoS) [20].

The temporal evolution of keywords. Then we decided to trace the temporal evolution of keywords (Scopus) and categories (WoS) (Table 5 and Table 6).

Table 5. Most used keywords (Scopus)

\begin{tabular}{|l|c|l|c|}
\hline \multicolumn{2}{|c|}{ For all the time (t1) } & \multicolumn{2}{c|}{ In 5 years (t1) } \\
\hline Keywords & $\begin{array}{l}\text { Number of } \\
\text { documents }\end{array}$ & \multicolumn{1}{|c|}{ Keywords } & $\begin{array}{l}\text { Number of } \\
\text { documents }\end{array}$ \\
\hline $\begin{array}{l}\text { Dangerous } \\
\text { Goods }\end{array}$ & 111 & $\begin{array}{l}\text { Dangerous } \\
\text { Goods }\end{array}$ & 18 \\
\hline Railway & 88 & Railroads & 18 \\
\hline Railroads & 80 & $\begin{array}{l}\text { Railroad } \\
\text { Transportation }\end{array}$ & 14 \\
\hline Article & 56 & $\begin{array}{l}\text { Railroad } \\
\text { Accidents }\end{array}$ & 12 \\
\hline $\begin{array}{l}\text { Risk } \\
\text { Assessment }\end{array}$ & 52 & $\begin{array}{l}\text { Risk } \\
\text { Assessment }\end{array}$ & 12 \\
\hline
\end{tabular}

\begin{tabular}{|l|c|l|c|}
\hline \multicolumn{2}{|c|}{ For all the time (t1) } & \multicolumn{2}{c|}{ In 5 years (t1) } \\
\hline \multicolumn{1}{|c|}{ Keywords } & $\begin{array}{l}\text { Number of } \\
\text { documents }\end{array}$ & \multicolumn{1}{|c|}{ Keywords } & $\begin{array}{l}\text { Number of } \\
\text { documents }\end{array}$ \\
\hline $\begin{array}{l}\text { Hazardous } \\
\text { Substances }\end{array}$ & 49 & Railway & 11 \\
\hline $\begin{array}{l}\text { Railroad } \\
\text { Transportation }\end{array}$ & 47 & $\begin{array}{l}\text { Freight } \\
\text { Transportation }\end{array}$ & 10 \\
\hline Human & 45 & $\begin{array}{l}\text { Hazardous } \\
\text { Substances }\end{array}$ & 7 \\
\hline $\begin{array}{l}\text { Hazardous } \\
\text { Materials }\end{array}$ & 35 & Rails & 7 \\
\hline Accidents & 33 & Transportation & 7 \\
\hline
\end{tabular}

The results show that among the most used keywords for $\mathrm{t} 2$ there are no words "Human" and "Hazardous Materials". But "Rails" and "Freight Transportation" began to be used more often.

To get the top keywords visualization, we used the VosViewer program. To work with it, the data from the Scopus database were saved in the format ris. With the help of Bibexel, which specializes in metadata processing, a file was created containing annotations of 193 documents.

Table 6. Most used Categories (WoS)

\begin{tabular}{|l|c|l|c|}
\hline \multicolumn{2}{|c|}{ For all the time } & \multicolumn{2}{c|}{ In 5 years } \\
\hline Categories & $\begin{array}{l}\text { Number } \\
\text { of docu- } \\
\text { ments }\end{array}$ & Categories & $\begin{array}{c}\text { Number } \\
\text { of docu- } \\
\text { ments }\end{array}$ \\
\hline $\begin{array}{l}\text { Transportation } \\
\text { science } \\
\text { technology }\end{array}$ & 23 & Transportation & 10 \\
\hline Transportation & 17 & $\begin{array}{l}\text { Transportation } \\
\text { science } \\
\text { technology }\end{array}$ & 10 \\
\hline $\begin{array}{l}\text { Operations } \\
\text { research } \\
\text { management } \\
\text { science }\end{array}$ & 14 & $\begin{array}{l}\text { Operations } \\
\text { research } \\
\text { management } \\
\text { science }\end{array}$ & 4 \\
\hline Engineering civil & 8 & $\begin{array}{l}\text { Engineering } \\
\text { civil }\end{array}$ & 3 \\
\hline $\begin{array}{l}\text { Engineering } \\
\text { mechanical }\end{array}$ & 8 & $\begin{array}{l}\text { Engineering } \\
\text { electrical } \\
\text { electronic }\end{array}$ & 3 \\
\hline $\begin{array}{l}\text { Engineering } \\
\text { electrical } \\
\text { electronic }\end{array}$ & 7 & $\begin{array}{l}\text { Engineering } \\
\text { industrial }\end{array}$ & 3 \\
\hline $\begin{array}{l}\text { Engineering } \\
\text { industrial }\end{array}$ & 7 & $\begin{array}{l}\text { Engineering } \\
\text { mechanical }\end{array}$ & 3 \\
\hline $\begin{array}{l}\text { Computer science } \\
\text { artificial } \\
\text { intelligence }\end{array}$ & 5 & $\begin{array}{l}\text { Social sciences } \\
\text { interdisciplinary }\end{array}$ & 3 \\
\hline $\begin{array}{l}\text { Computer science } \\
\text { interdisciplinary } \\
\text { applications }\end{array}$ & 5 & $\begin{array}{l}\text { Telecommunicat } \\
\text { ions }\end{array}$ & 3 \\
\hline $\begin{array}{l}\text { Engineering } \\
\text { chemical }\end{array}$ & 5 & $\begin{array}{l}\text { science } \\
\text { information } \\
\text { systems }\end{array}$ & 2 \\
\hline
\end{tabular}

The results were then imported into the VosViewer program for visualization. In cluster analysis, the link layer was taken at least 10 .

It is clearly seen (Fig.4) that the TDG research topic has formed 4 clusters, and each cluster has its own color. 
Conventional cluster names: "Research \& Development" - green, "Train \& Assessment" - red, "Impact \& Article" - yellow, "Railway \& Security" - blue. There is a significant correlation between keywords in each cluster. Reading the map "The keywords co-occurrence network of TDG studies", we see that the most intense and extensive connections between the co-authors and the analyzed annotations formed keyword nodes in the red cluster. These are the subtopics associated with the research of TDG.

Continuing further to monitor the temporal evolution of keywords, we turned to Categories (WoS) for $t 2$ and discovered the emergence of new terms: "Social sciences interdisciplinary", "Telecommunications", "Computer science information systems" (Table 6).

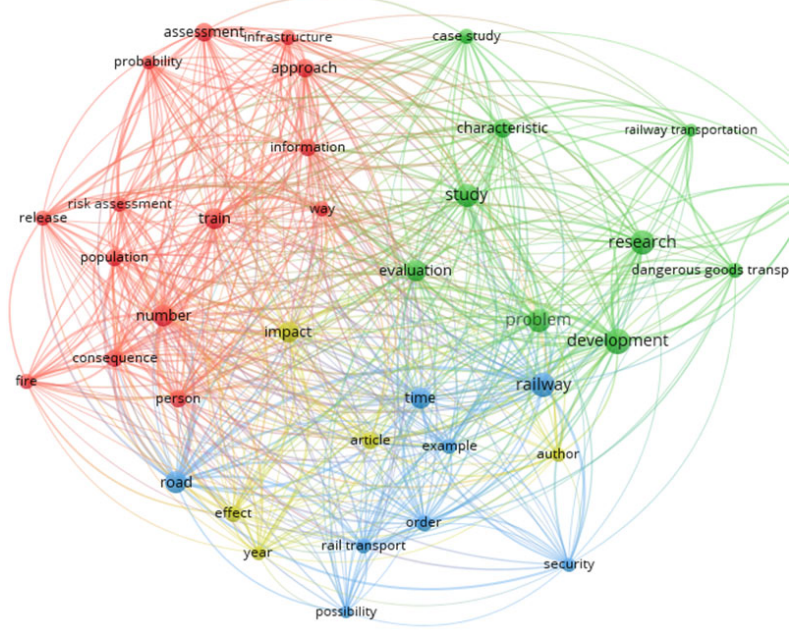

Fig. 4. The keywords co-occurrence network of TDG studies.

Table 7. Organizations, the authors of which have published at least 3 papers

\begin{tabular}{|l|c|l|c|}
\hline \multicolumn{2}{|c|}{ Scopus, 1975-2019 } & \multicolumn{2}{c|}{ WoS, 1997 - 2019 } \\
\hline Organization & $\begin{array}{l}\text { Number of } \\
\text { documents }\end{array}$ & Organization & $\begin{array}{l}\text { Number of } \\
\text { documents }\end{array}$ \\
\hline $\begin{array}{l}\text { Beijing } \\
\text { Jiaotong } \\
\text { University }\end{array}$ & 15 & $\begin{array}{l}\text { Beijing } \\
\text { Jiaotong } \\
\text { University }\end{array}$ & 8 \\
\hline $\begin{array}{l}\text { Southwest } \\
\text { Jiaotong Univ }\end{array}$ & 10 & $\begin{array}{l}\text { Mcgill } \\
\text { University }\end{array}$ & 6 \\
\hline $\begin{array}{l}\text { University of } \\
\text { Illinois at } \\
\text { Urbana- } \\
\text { Champaign }\end{array}$ & 6 & $\begin{array}{l}\text { Iran University } \\
\text { Science } \\
\text { Technology }\end{array}$ & 5 \\
\hline $\begin{array}{l}\text { University of } \\
\text { Waterloo }\end{array}$ & 5 & $\begin{array}{l}\text { Mcmaster } \\
\text { University }\end{array}$ & 4 \\
\hline $\begin{array}{l}\text { Iran University } \\
\text { of Science and } \\
\text { Technology }\end{array}$ & 4 & $\begin{array}{l}\text { Memorial } \\
\text { University } \\
\text { Newfoundland }\end{array}$ & 4 \\
\hline $\begin{array}{l}\text { Queen's } \\
\text { University, } \\
\text { Kingston }\end{array}$ & 4 & $\begin{array}{l}\text { University of } \\
\text { Genoa }\end{array}$ & 4 \\
\hline $\begin{array}{l}\text { McGill } \\
\text { University }\end{array}$ & 3 & $\begin{array}{l}\text { University of } \\
\text { Florence }\end{array}$ & 3 \\
\hline $\begin{array}{l}\text { Lanzhou } \\
\text { Jiaotong } \\
\text { University }\end{array}$ & $\begin{array}{l}\text { University of } \\
\text { Waterloo }\end{array}$ & 3 \\
\hline
\end{tabular}

\begin{tabular}{|l|c|c|c|}
\hline \multicolumn{2}{|c|}{ Scopus, 1975-2019 } & \multicolumn{2}{c|}{ WoS, 1997 - 2019 } \\
\hline Organization & $\begin{array}{l}\text { Number of } \\
\text { documents }\end{array}$ & Organization & $\begin{array}{l}\text { Number of } \\
\text { documents }\end{array}$ \\
\hline $\begin{array}{l}\text { Università } \\
\text { degli Studi di } \\
\text { Genova }\end{array}$ & 3 & & \\
\hline $\begin{array}{l}\text { Università } \\
\text { degli Studi di } \\
\text { Roma La } \\
\text { Sapienza }\end{array}$ & 3 & & \\
\hline $\begin{array}{l}\text { Vilniaus } \\
\text { Gedimino } \\
\text { Technikos } \\
\text { Universitetas }\end{array}$ & 3 & & \\
\hline $\begin{array}{l}\text { Desautels } \\
\text { School of } \\
\text { Management }\end{array}$ & 3 & & \\
\hline
\end{tabular}

The organizations and countries. The categorization by organization whose authors published at least 3 papers for $\mathrm{t} 1$, shown in Table 9, shows the top 12 universities of the world in the Scopus database. The results for the WoS DB are more modest. The leader in the number of publications in each of the databases (Scopus and WoS) became Beijing Jiaotong University (China).

According to the search results, all TDG research works originate from 29 countries (or territories) of the world. 18 publications had no information about the origin of the authors. Top 10 countries whose scientists were more productive for $\mathrm{t} 1$, according to Scopus DB: China (40), United States (29), Canada (19), Italy (12), Germany (9), France (6), Netherlands (6), Iran (5), Switzerland (5), Lithuania (4). But for t2, the researchers of most of these countries have lost interest in this topic. Researchers from China (8), Canada (6), Italy (3), France (4) are still active.

The results of the analysis of data obtained from the WoS database for $\mathrm{t} 1$ with a similar search are as follows: Canada (16), Peoples r China (16), Italy (12), USA (8), Iran (7), Germany (6), France (4), England (3), Greece (3), Lithuania (3). But for $t 2$, only researchers from 4 countries were interested in the topic of TDG: Canada (7), Peoples r China (6), Italy (4), USA (5).

Number of documents by type. The most popular types of documents in the Scopus and WoS databases have become Article, Conference (Proceedings) Paper, Review (Table 8).

Table 8. Number of documents by type (Scopus, WoS)

\begin{tabular}{|l|c|c|}
\hline \multirow{2}{*}{ Document type } & \multicolumn{2}{|c|}{ Number of documents } \\
\cline { 2 - 3 } & $\begin{array}{c}\text { For all the time } \\
\text { Scopus / WoS }\end{array}$ & $\begin{array}{c}\text { In 5 years } \\
\text { Scopus / WoS }\end{array}$ \\
\hline Article & $128 / 41$ & $20 / 20$ \\
\hline $\begin{array}{l}\text { Conference } \\
\text { (Proceedings) Paper }\end{array}$ & $43 / 46$ & $16 / 17$ \\
\hline Review & $9 / 3$ & $0 / 3$ \\
\hline Conference Review & $8 / 0$ & $2 / 0$ \\
\hline Note & $2 / 0$ & $0 / 0$ \\
\hline Editorial & $1 / 0$ & $0 / 0$ \\
\hline Erratum & $1 / 0$ & $0 / 0$ \\
\hline Letter & $1 / 0$ & $0 / 0$ \\
\hline
\end{tabular}


Documents by branches of knowledge. The multidisciplinarity of the TDG topic is confirmed by the presence of publications in 20 branches of knowledge. The distribution of the number of publications (at least 4) for $\mathrm{t} 1$ and $\mathrm{t} 2$ is shown in Table 9.

Categorization by language. In the general search, the overwhelming majority of all analyzed publications were written in English: Scopus - 77.72\% (t1) and 97.37\% (t2); WoS - 95.4\% (t1) and 97.5\% (t2). The second language in the number of publications was Chinese, but only in an insignificant number: Scopus $8.29 \%(\mathrm{t} 1)$ and $5.26 \%(\mathrm{t} 2)$; WoS $-2.3 \%(\mathrm{t} 1)$ and $2.5 \%$ (t2). All other languages, although present in Scopus publications for t1, for example, Russian (12), German (9), French (3); but for t2 there were no such publications (Table 10).

Table 9. Documents by branches of knowledge

\begin{tabular}{|c|c|c|c|}
\hline \multirow[b]{2}{*}{ Branch of knowledge } & \multicolumn{2}{|c|}{ Number of documents } & \multirow{2}{*}{$\begin{array}{c}\% \text { new } \\
\text { documents }\end{array}$} \\
\hline & $\begin{array}{c}\text { For all } \\
\text { the time }\end{array}$ & $\begin{array}{c}\text { In 5 } \\
\text { years }\end{array}$ & \\
\hline Engineering & 88 & 21 & $23,86 \%$ \\
\hline Medicine & 52 & 8 & $15,38 \%$ \\
\hline Social Sciences & 50 & 17 & $34,00 \%$ \\
\hline Environmental Science & 36 & 4 & $11,11 \%$ \\
\hline Computer Science & 22 & 5 & $22,73 \%$ \\
\hline Chemical Engineering & 16 & 3 & $18,75 \%$ \\
\hline $\begin{array}{l}\text { Business, Management } \\
\text { and Accounting }\end{array}$ & 10 & 3 & $30,00 \%$ \\
\hline Mathematics & 10 & 4 & $40,00 \%$ \\
\hline Decision Sciences & 9 & 2 & $22,22 \%$ \\
\hline Chemistry & 5 & 2 & $40,00 \%$ \\
\hline Energy & 5 & 3 & $60,00 \%$ \\
\hline $\begin{array}{l}\text { Agricultural and } \\
\text { Biological Sciences }\end{array}$ & 4 & 2 & $50,00 \%$ \\
\hline
\end{tabular}

Table 10. Number of documents by languages (Scopus, WoS)

\begin{tabular}{|l|c|c|}
\hline \multirow{2}{*}{ Language } & \multicolumn{2}{|c|}{ Number of documents } \\
\cline { 2 - 3 } & $\begin{array}{c}\text { For all the time } \\
\text { Scopus / WoS }\end{array}$ & $\begin{array}{c}\text { In 5 years } \\
\text { Scopus / WoS }\end{array}$ \\
\hline English & $150 / 83$ & $37 / 39$ \\
\hline Chinese & $16 / 2$ & $2 / 1$ \\
\hline Russian & $12 / 0$ & $0 / 0$ \\
\hline German & $9 / 1$ & $0 / 0$ \\
\hline French & $3 / 0$ & $0 / 0$ \\
\hline Dutch & $1 / 0$ & $0 / 0$ \\
\hline Italian & $1 / 0$ & $0 / 0$ \\
\hline Polish & $1 / 0$ & $0 / 0$ \\
\hline Portuguese & $0 / 1$ & $0 / 0$ \\
\hline Spanish & $1 / 0$ & $0 / 0$ \\
\hline
\end{tabular}

Categorization by Financial Sponsors. The results of the study fix a fairly small financial support for the TDG topic in different countries. According to the Scopus database the financial sponsors are 18 organizations: Natural Sciences and Engineering Research Council of Canada $(\mathrm{n}=5)$, Association of American Railroads $(\mathrm{n}=2)$, College of Natural Resources, University of California Berkeley $(n=2)$, National Natural Science Foundation of China $(n=2)$, National Research Council $(n=2)$. Another 13 organizations funded one project each: Alberta Innovates; Centre National pour la Recherche Scientifique et Technique; City, University of London; Dow Chemical Company; Dwight D. Eisenhower Army Medical Center; Generalitat Valenciana; Institut d'Estudis Catalans; Korea National Railroad College University; Ministero dell'Istruzione, dell'Università e della Ricerca; Ministry of Infrastructure, Transport and Networks; National Research Council Canada; Northwestern University Transportation Center; Rutgers, The State University of New Jersey.

From the publications presented in the WoS, it follows that financial support for research was provided by 18 organizations. Herwith, 3 publications were supported by the Natural Sciences and Engineering Research Council of Canada $(\mathrm{n}=3)$. Another 17 organizations supported one project each: Department of Civil and Environmental Engineering at Rutgers; Ansaldo Sts.; Association of American Railroads BNSF Railway; collaboratively Center for Advanced Infrastructure and Transportation an Office of the Assistant Secretary for Research and Technology US, Department of Transportation Designated National University, Transportation Center at Rutgers the State University of New Jersey; French Program of Research and Innovation in Terrestrial Transport Predit; Fundamental Research Funds for the Central Universities; Generalitat Valenciana Spain; Ministry of Education and Science of the Republic of Srbia; Mitacs Globalink Scholarship; National University Rail Center a US Dot Rita University Transportation Center; Natural Science Foundation of China NSFC; School of Engineering at Rutgers; Security Capacity Construction Foundation of Civil Aviation Authority of China; Social Sciences and Humanities Research Council of Canada; University of Genova. We note that according to the Scopus and WoS databases, the largest amount of researches was supported by the National Sciences and Engineering Research Council of Canada.

\section{Conclusions}

In the present study, we evaluated the flow of publications of the global research environment in the field of transportation of dangerous goods by a particular mode of transport - rail. We used a combination of bibliometric tools, scientometric analysis and new visualization methods.

The growth of international and domestic transport of dangerous goods leads to increased risk for transportation hubs and nearby settlements, as well as the emergence of environmental and safety hazards. Of course, these questions are in the focus of attention of researchers, as evidenced by the increase in the number of publications over the past 5 years in the Scopus database $-38(\mathrm{t} 1=193)$ and Web of Science $-40(\mathrm{t} 1=$ $87)$. The Scopus database indexes more publications on the TDG topic than the WoS database. In general, from 1975 to June 2019 (t1), the oscillatory tendency remained with respect to the frequency of published works. For example, a decrease in the number of 
publications in 1998-1999 and 2007-2009 can be associated with global financial crises that began in 1998 and 2008. The likelihood of another global spiral of financial problems (possibly in 2020) increases the likelihood of reducing the amount of research on the TDG topic.

However, the increase in the number of publications can also be affected by the increase in the number of such type of document as Conference (Proceedings) Paper, affecting the search procedure. This was observed in our study. For $\mathrm{t} 2$ in each of the databases, the number of Article and Conference (Proceedings) Paper became almost equal. So, in Scopus - respectively 20/20, WoS $16 / 17$.

The multidisciplinarity of the TDG topic is confirmed by the presence of publications in 20 branches of knowledge.

Bibliometric visualization using VOSviewer (Fig. 2) allowed us to identify two research clusters with the most powerful interrelationships. This is first of all the red "Train \& Assessment" cluster with sub-topics: approach, infrastructure, risk assessment, release, consequence, number, person, probability, population, way, information. In the green "Research \& Development" cluster it was shown that the most intense and extensive links between co-authors and analyzed annotations were formed by the following keyword nodes - sub-topics: study, evaluations, railway transportation, characteristic, problem, case study, china, dangerous goods.

In addition to bibliometric visualization, analyzing statistical data by the number of documents, we have noted in the last 5 years (from 2015 to June 2019) for Scopus and WoS a decreased interest of researchers in the subject area "Locomotives" and increased interest in new subject areas: "Automation and telematics systems", "Navigation systems", "Logistics", "Energy". Categories (WoS) for $\mathrm{t} 2$ also demonstrate the activity of researchers in new areas "Social sciences interdisciplinary", "Telecommunications", "Computer science information systems". It is obvious that research in these areas are promising global scientific trends in the field of transportation of various dangerous goods by rail.

Both visualization and statistical analysis provide insights into the research environment and can help with the choice of the research topic and the outlook for TDG researchers.

The main journals of interest to the authors for a long time include "Safety Science", "Accident Analysis and Prevention" and "Tiedao Xuebao Journal of the China Railway Society". But 2 of the most highly cited to date articles on TDG were published in "Journal of Hazardous Materials". Their authors are P. H. Bottelberghs (Netherlands) and B. Fabiano, F. Currò, E. Palazzi, R. Pastorino (Italy).

According to the search results, all TDG research works originate from 29 countries (or territories) of the world. In recent years ( $\mathrm{t} 2$ ), by Number of documents by countries and territories, the leading positions belong to the researchers from: by Scopus database - China, Canada, Italy, France; WoS DB - Canada, China, Italy, USA.
Analysis of the author publication activity showed that the most productive authors are from the following countries: Russian Federation, Iran, United States, Canada, China.

Analysis by organization identified the leader in the number of publications in each of the databases (Scopus and WoS) - Beijing Jiaotong University (China). But the analysis in the aspect of joint research by scientists from different countries shows a very low level of interaction.

Categorization by language made it possible to establish an unconditional increase in the number of publications in English. In each of the databases (Scopus and WoS) for $\mathrm{t} 2$, this number is more than $97 \%$.

There is an obvious link between how the state invests in scientific research and its economic power. But the results of our study fix a small financial support for TDG topic in different countries. Financial sponsors are 18 organizations. According to the Scopus and WoS databases, the largest number of researches was supported by the National Sciences and Engineering Research Council of Canada.

\section{Originality / Value}

As far as the authors know, this is the first study focused on a bibliometric analysis of the global flow of scientific publications on the transport of dangerous goods by rail. The results of the study can be a guide, stimulating and directing interested researchers for further study.

\section{References}

1. Yu.V. Zelenko, I.L. Zhuravel, A.M. Okorokov, O.M. Patlasov, A.M Boichenko, and H.I. Nesterenko. Posibnyk dlia kursu spetsialnoho navchannia $z$ pytan perevezen nebezpechnykh vantazhiv na zaliznychnomu transporti. Chastyna 1. Bazovyi kurs. Available at http://eadnurt.diit.edu.ua/bitstream/123456789/8821 /1/Textbook.pdf (2015)

2. BusinessDictionary. Available at $\mathrm{http} / /$ www.businessdictionary.com/definition/dange rous-goods.html (n. d.)

3. M. Šolc, and M. Hovanec. The Importance of Dangerous Goods Transport by Rail. Naše more 62, 181-186. DOI: 10.17818/NM/2015/SI17 Available at http://www.nasemore.com/the-importance-ofdangerous-goods-transport-by-rail/ (2015)

4. Convention concerning International Carriage by Rail (COTIF). Appendix C - Regulations concerning the International Carriage of Dangerous Goods by Rail (RID). Available at https://otif.org/fileadmin/new/3-Reference-Text/3BRID/RID\%202019\%20E.pdf (2019)

5. F.H. Qaiser, K. Ahmed, M. Sykora, A. Choudhary, and M. Simpson. Decision support systems for sustainable logistics: a review and bibliometric analysis. Ind Manag Data Syst, 117(7), 1376-1388. DOI: https://doi.org/10.1108/IMDS-09-2016-0410) (2017). 
6. S. Gruner, A. Kumar, and T. Maibaum. Towards a Body of Knowledge in Formal Methods for the Railway Domain: Identification of Settled Knowledge. $\quad C C I S, \quad 596, \quad 87-102 . \quad$ DOI: https://doi.org/10.1007/978-3-319-29510-7_5 (2016).

7. L. Yaryshkina, and A. Boychenko. Development of the Efficient Technology for Eliminating Environmental Aftermaths in Transport. Transport Problems. 5(10), 113-118 (2010).

8. A. Samarska, and Y. Zelenko. Assessment of the Railway Influence on the Heavy Metal Accumulation in Soil. Science and Transport Progress, 4(75), 25-35. DOI: http://dx.doi.org/10.15802/stp2018/140551

Available http://stp.diit.edu.ua/article/view/140551/147604 (2018)

9. B. Groneberg-Kloft, D. Klingelhoefer, S. E. Zitnik, and C. Scutaru. Traffic medicine-related research: a scientometric analysis. BMC Public Health, 13, 541. DOI: $\quad$ https://doi.org/10.1186/1471-2458-13-541 (2013)

10. S. Kolesnykov. Improvement of Life Support Systems of Passenger Rolling Stock: Patent Review. Science and Transport Progress, 1(73), 44-55. DOI: http://dx.doi.org/10.15802/stp2018/123460

Available http://stp.diit.edu.ua/article/view/123460/120313 (2018)

11. C. Wei, R. Ma, and X. Wang. An Analysis of Policy and Management Mode of Urban Rail Transit Safety in Developed Countries. Proceedings of 2014 International Conference on Public Administration, II, 961-967 (2014)

12. J.L.S. Santos, M. Uriona-Maldonado, and R.N.M.D. Santos. Inovação e conhecimento organizacional: um mapeamento bibliométrico das publicações científicas até 2009. Revista Organizações em Contexto, 7(13), 31-58 (2011)

13. F. Åström, R. Danell, B. Larsen, and J. Schneider (Eds.) Celebrating Scholarly Communication Studies: A Festschrift for Olle Persson at his 60th Birthday, 9-24 (ISSI, 2009)

14. T. Kolesnykova, and O. Matveyeva. Performance Assesment of the Research: Bibliometrics. Science and Transport Progress, 4(58), 7-22. DOI: http://dx.doi.org/10.15802/stp2015/49190 Available at http://stp.diit.edu.ua/article/view/49190/49145 (2015)

15. N.J. van Eck, and L. Waltman. Software survey: VOSviewer, a computer program for bibliometric mapping. Scientometrics, 82(2), 523-538 Available at https://akademiai.com/doi/pdf/10.1007/s11192009-0146-3 (2010)

16. J. Chen, Y. Su, H. Si, and J. Chen. Managerial Areas of Construction and Demolition Waste: A Scientometric Review. IJERPH, 15(11), 2350. (2018)

17. P. H. Bottelberghs. Risk analysis and safety policy developments in the Netherlands. J Hazard Mater, 71(1-3), 59-84. DOI: $10.3390 /$ ijerph 15112350 (2000).

18. B. Fabiano, F. Currò, E. Palazzi, R. Pastorino. A framework for risk assessment and decision-making strategies in dangerous good transportation. $J$ Hazard Mater, 93(1), 1-15 (2002)

19. M. Bagheri, F. Saccomanno , S. Chenouri, and L. Fu. Reducing the threat of in-transit derailments involving dangerous goods through effective placement along the train consist. Accid Anal Prev, 43(3), 613-620. DOI: 10.1016/j.aap.2010.09.008 (2011)

20. M. Bagheri, M. Verma, V. Verter. Transport Mode Selection for Toxic Gases: Rail or Road? Risk Analysis, 34(1), 168-186. DOI: 10.1111/risa.12063 (2014) 